\title{
PERIWINKLE (GASTROPODA: LITTORINIDAE) HABITAT SELECTION AND ITS IMPACT UPON MICROALGAL POPULATIONS
}

\author{
APOLINÁRIO, M., ${ }^{1}$ COUTINHO, R. ${ }^{2}$ and BAETA-NEVES, M. H. ${ }^{2}$ \\ ${ }^{1}$ Museu Nacional, Departamento de Invertebrados, Carcinologia, Universidade Federal do Rio de Janeiro, \\ CEP 20940-040, Rio de Janeiro, RJ, Brazil \\ ${ }_{2}^{2}$ Instituto de Estudos do Mar Almirante Paulo Moreira, Arraial do Cabo, RJ, Brazil \\ Correspondence to: Moacir Apolinário, Museu Nacional, Departamento de Invertebrados, Carcinologia, Universi- \\ dade Federal do Rio de Janeiro, CEP 20940-040, Rio de Janeiro, RJ, Brazil, e-mail: a.moa@uol.com.br \\ Received September 19, 1997 - Accepted October 06, 1998 - Distributed June 30, 1999
}

(With 3 figures)

\begin{abstract}
The present study examines habitat selection and grazing pressure of the periwinkle Nodilittorina lineolata (Gmelin, 1791) on the rocky shore of Arraial do Cabo, RJ, Brazil (lat. $23^{\circ} \mathrm{S}$, long. $43^{\circ} \mathrm{W}$ ). Transfer experiments suggest that periwinkles actively select the mid intertidal, where the cirripede Chthamalus bisinuatus Pilsbry is the dominant sessile invertebrate. We also conducted a caging experiment in the middle intertidal, manipulating grazers and light, to assess the impact of grazing upon microalgal density. Grazing pressure significantly reduced microalgal abundance at the midintertidal level, suggesting that food availability plays an important role in the habitat selection of periwinkles on the studied shore.
\end{abstract}

Key words: Brazil, habitat selection, intertidal, Littorinidae, microalgae.

\section{RESUMO}

\section{Seleção de hábitat de gastrópodes Littorinidae e seu impacto} sobre populações de microalgas

O presente estudo examina seleção do hábitat e pressão de herbivoria pelo gastrópode Nodilittorina lineolata (Gmelin, 1791) no costão rochoso de Arraial do Cabo, RJ, Brasil (lat. $23^{\circ} \mathrm{S}$, long. $43^{\circ} \mathrm{W}$ ). Experimentos de transferência sugerem que os gastrópodos selecionam ativamente a região do médio-litoral, em que o cirripédio Chthamalus bisinuatus Pilsbry é o invertebrado séssil dominante. Nós também conduzimos um experimento de exclusão, com gaiolas, no médio-litoral, manipulando os herbívoros e luz, para acessar o impacto da herbivoria sobre a densidade de microalgas. A pressão de herbivoria reduziu significativamente a abundância de microalgas no médiolitoral, sugerindo que a disponibilidade de alimento exerce um papel importante na seleção do hábitat dos gastrópodos estudados.

Palavras-chave: Brasil, Littorinidae, microalgas, seleção de hábitat.

\section{INTRODUCTION}

Periwinkles (Gastropoda: Littorinidae) are found from high to low levels in the intertidal zones of shores all over the world. Much has been published on ecological factors affecting the vertical distribution of periwinkles, with different conclusions about the most important ones such as wave exposure, desiccation and temperature (Petraits, 1982; Campos, 1985; Bosh \& Moreno, 1986; Vaughn \& Fisher, 1988; Takada, 1992, 1995). Periwinkles and other benthic invertebrates play an important role in controlling the structure of intertidal communities. Cubit (1984) demonstrated the role of herbivores in controlling macroalgae of the intertidal zone in Oregon, USA. However, 
the role of Littorinidae on the microalgal flora has always been neglected due to sampling and experimental manipulation difficulties with microalgaes. A recent study carried out by Faust \& Gulledge (1996) has shown that benthic microalgae serve as a food resource for intertidal gastropods and play an important role in tropical marine environment. The role of other biological processes such as competition and predation) in structuring intertidal communities has been more traditionally emphasized by several authors (Underwood, 1984a, b and c; Raffaelli, 1985; Watson \& Norton, 1985, 1987).

Mobile intertidal animals, such as periwinkles, can respond to differences in microhabitats along a vertical gradient and change their behavior in response to different environmental conditions (Byers \& Mitton, 1981; Garrity \& Levings, 1984; Fairweather, 1988; Underwood \& Chapman, 1989). A complex topography separated by only a few meters can be an important factor of population patchness for intertidal mollusks (Chapman \& Underwood, 1994). Crowe (1996), suggested that models predicting patterns of movement in intertidal gastropods must incorporate information about the age of the animals, the arrangement of the microhabitat and the habitat they occupy.

Along the rocky shores of Arraial do Cabo, southwestern Brazil, the upper midlittoral fringe is usually called as "Littorinid zone". However, we have been observing that littorinids are much more abundant in the middle-intertidal zone aggregating amongst cirripedes (Coutinho, unpublished data). A traditional explanation for this observed phenomenon would be that the high intertidal is extremely hot (especially during the tropical summer), and that littorinids would avoid such stress. We tend to agree with this general view; however we believe that food resource is a much more important factor operating on patterns of movement and distribution of populations. From that point of view, we experimentally transferred periwinkles (Nodilittorina lineolata) from different intertidal levels and manipulated the access of periwinkles to experimental areas (using cages, fences and roofs) to test our hypotheses that the presence of periwinkles at the middle intertidal reduce the abundance of microalgal populations, suggesting that food supply could be an explanation for the observed pattern of distribution of periwinkles at that intertidal shore.

\section{MATERIAL AND METHODS}

\section{Study site}

Arraial do Cabo (lat. $23^{\circ} \mathrm{S}$, long. $43^{\circ} \mathrm{W}$ ), located in the State of Rio de Janeiro, southwestern Brazil, has a tropical climate with summer (November-April) winds predominantly from the east and northeast and winter winds from the south and southwest. Sea temperatures range from $19^{\circ}$ to $24^{\circ} \mathrm{C}$. Tidal amplitudes vary between 30 and 120 $\mathrm{cm}$. The rocky shore at our site, Forno, receives most wind/wave stresses during the winter. The shore slope varies from $40^{\circ}$ to $60^{\circ}$ and therefore there is space limitation. Zonation is well delimited within the intertidal zone with the lower intertidal (60 to $90 \mathrm{~cm}$ below mean high tide level) dominated by the bivalve Brachidontes solisianus, the middle intertidal $(30-60 \mathrm{~cm})$ by the cirripede Chthamalus bisinuatus Pilsbry, and the upper intertidal $(0-30 \mathrm{~cm})$ with a low density of the gastropod Nodilittorina lineolata.

\section{Transfer manipulation}

Nine pairs of $120 \mathrm{~cm}$ long by $40 \mathrm{~cm}$ wide vertical transects from high to low tide water levels served as the experimental plots. Because of limited space on the rocky shore, we ran just 1 replicate of each treatment. Periwinkles (Nodilittorina lineolata) were transferred from outside of the experimental plots. The natural densities of periwinkles in the upper, middle, and lower intertidal zones averaged 0.5, 2.5, and 0.6 individuals $\mathrm{cm}^{-2}$, respectively (Coutinho, unpublished data).

Before each transfer experiment, all periwinkles were removed from the transects. Three sets of 50 randomly sampled periwinkles from each third of the intertidal zone, marked with small dots of paint to distinguish their zone of origin, were transferred to each of the three levels in separate periwinkle free transects (Table 1), making 9 total treatments, each with 50 periwinkles. The distribution of marked periwinkles with respect to the 3 levels of their intertidal zone was then measured every 4 hours for 24 hours with a $30 \mathrm{~cm}^{2}$ quadrat. The 3 treatments in which the transferred periwinkles were placed in the same zones from which they have been collected (U/U, M/M, L/L) served as controls, for the number of periwinkles that would stay at their original zone (despite being subject of density dependent effect due to the high 
TABLE 1

Periwinkle transfer treatments. Periwinkles randomly sampled from each third of the intertidal zone were transferred, in batches of 50 individuals, into separate cleared transects at each of the intertidal levels, upper $(0-30 \mathrm{~cm}$ below the high tide level), middle $(30-60 \mathrm{~cm})$, and lower $(60-90 \mathrm{~cm})$.

\begin{tabular}{|l|c|c|c|}
\hline & \multicolumn{3}{|c|}{ Source } \\
Destination & Low & Mid & Upper \\
\hline Low & L/L & M/L & U/L \\
\hline Mid & L/M & M/M & U/M \\
Upper & L/U & M/U & U/U \\
\hline
\end{tabular}

number of marked periwinkles). The experiment was carried out twice, in July (winter) and December (summer).

The distribution data from this transfer experiment underwent the square root transformation, to ensure equality of variances, and then arcsine transformation, before running a 2 way ANOVA to assess the significance of differences between transfers and seasons.

\section{Grazer exclusion experiment}

We tested the hypothesis that periwinkles have a significant impact upon microalgal populations by manipulating light and periwinkle access to the substrate during mid-August with roofing and/or fencing. The first treatment was the control which received normal light and from which we did not exclude periwinkles (no fence, no roof). The second treatment was a fence that excluded all periwinkles with normal light (fence - roof). The third treatment was roofed but did not exclude periwinkles (roof - fence). The fourth treatment was a full cage that excluded all periwinkles and shadowed the substrate (fence + roof). Cages, fences and roofs were made with $15 \mathrm{~cm}^{2}$ aluminum bars and $1 \mathrm{~mm}$ mesh size nylon net. Roofs were suspended $10 \mathrm{~cm}$ above the rocky shore by four steel bolts inserted into holes drilled into the rock. A RYO-BI ${ }^{\mathrm{TM}}$ gasoline powered hammer drill was used to fix the fences and cages.

We used 4 replicates per treatment on plots distributed randomly in the middle intertidal. The rock surface on the plots was scraped (before and after 45 days inside each cage type) to a depth at which there was no further coloration of the rock (0.2-0.6 mm). Such samples yielded 2-3 g of rock particles and associated microalgae (Cyanophyceae, Diatomaceae) from an area that ranged from 2 to
$5 \mathrm{~cm}^{2}$. Rock-scrapings were placed into test tubes with $10 \mathrm{ml}$ of $90 \%$ acetone. In the laboratory, chlorophyll- $a$ was extracted from the samples by centrifuging the tubes to separate all the rock dust, and then measured in a spectrophotometer according to the method of Jeffrey \& Humphrey (1975). Finally, the concentration of chlorophyll a was converted to $\mathrm{mg} . \mathrm{cm}^{2}$.

Data were square root transformed to ensure the homogeneity of variances before running a twoway ANOVA to assess the significance of time (before and after 45 days) and treatment (4 cage types). Fisher's protected LSD test was conducted to assess the significance of differences among the 4 cage types.

\section{RESULTS}

\section{Transfer manipulation}

Despite a very hot summer and a windy/wavy winter, we could not detect significant differences in periwinkle distribution between the two seasons for transferred periwinkles found in the upper, middle and lower intertidal levels $(\mathrm{p}=0.7073$, $0.5609,0.3657$, respectively). For both experiments, periwinkles transferred from one zone to the others, tended to move and aggregate into the middle intertidal (Fig. 1).

For those periwinkles collected and released into their zones of origin (control), a similar pattern of movement into the middle intertidal was observed (Fig. 2). These results suggest that physical factors, such as temperature and humidity are not determinant for periwinkle vertical distribution at this particular rocky shore.

Providing a high number of marked animals to transplant from/to each intertidal level $(n=50)$, we caused density-dependence effect in our data. 


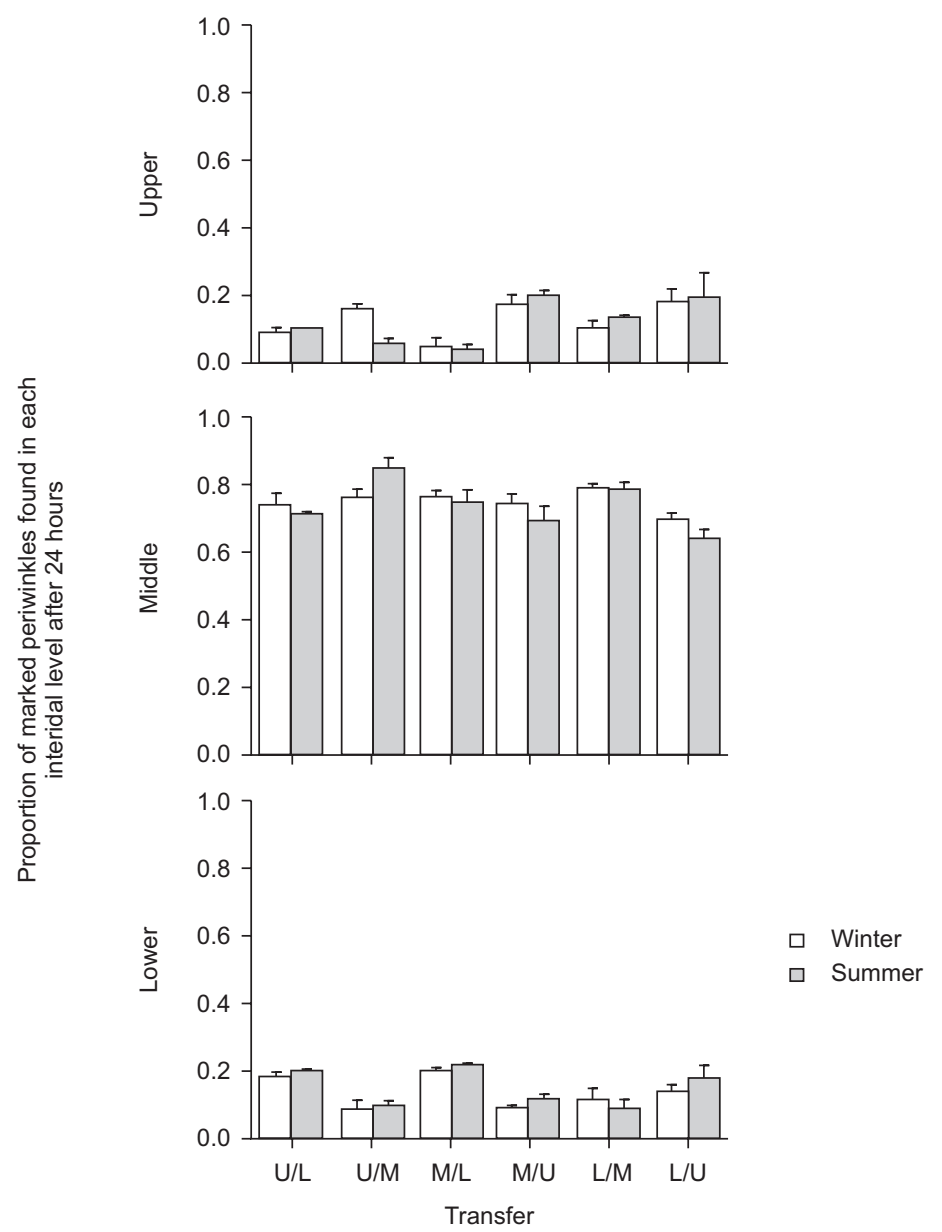

Fig. 1 - Distribution of marked periwinkles in the upper, middle and lower intertidal 24 hours after transfer, for Winter and Summer experiments. Treatments are identified by source/destination zones within the intertidal zone (upper $=\mathrm{U}=0$ to $30 \mathrm{~cm}$ down slope from the high tide level, middle $=\mathrm{M}=30$ to $60 \mathrm{~cm}$ down, and lower $=\mathrm{L}=60$ to $90 \mathrm{~cm}$ down).

This was necessary due to problems of loosing marked animals (by several factors such as, predation, and specially wave dislodgment), and also because of nocturnal sampling. However, comparing the percentage data of marked periwinkles at each intertidal level with the percentage data of the natural vertical distribution of periwinkles, we can assume that handling effect was negligeble.

Another important part of our methodology is the option for sampling at 4 hour interval, even tough we were just interested in the before/after 24 hour data. We used this method as a way to monitor the patterns of movement through time. As we observed a clear temporal pattern of mo- vement towards the middle intertidal, our figures show only the before/after results for each transfer manipulation.

\section{Grazer exclusion experiment}

At the beginning of the experiment, chlorophyll- $a$ concentrations ranged from 0.20 to 0.25 mg.cm ${ }^{-2}$ among the 4 cage types. After 45 days, cage and fence treatments had their concentrations of chlorophyll- $a$ increased, while the treatments roof and control (open) decreased.

It is clear the interaction between the two groups of treatments; the one that have excluded the grazers and the other that have manipulated the physical factor (Fig. 3). 


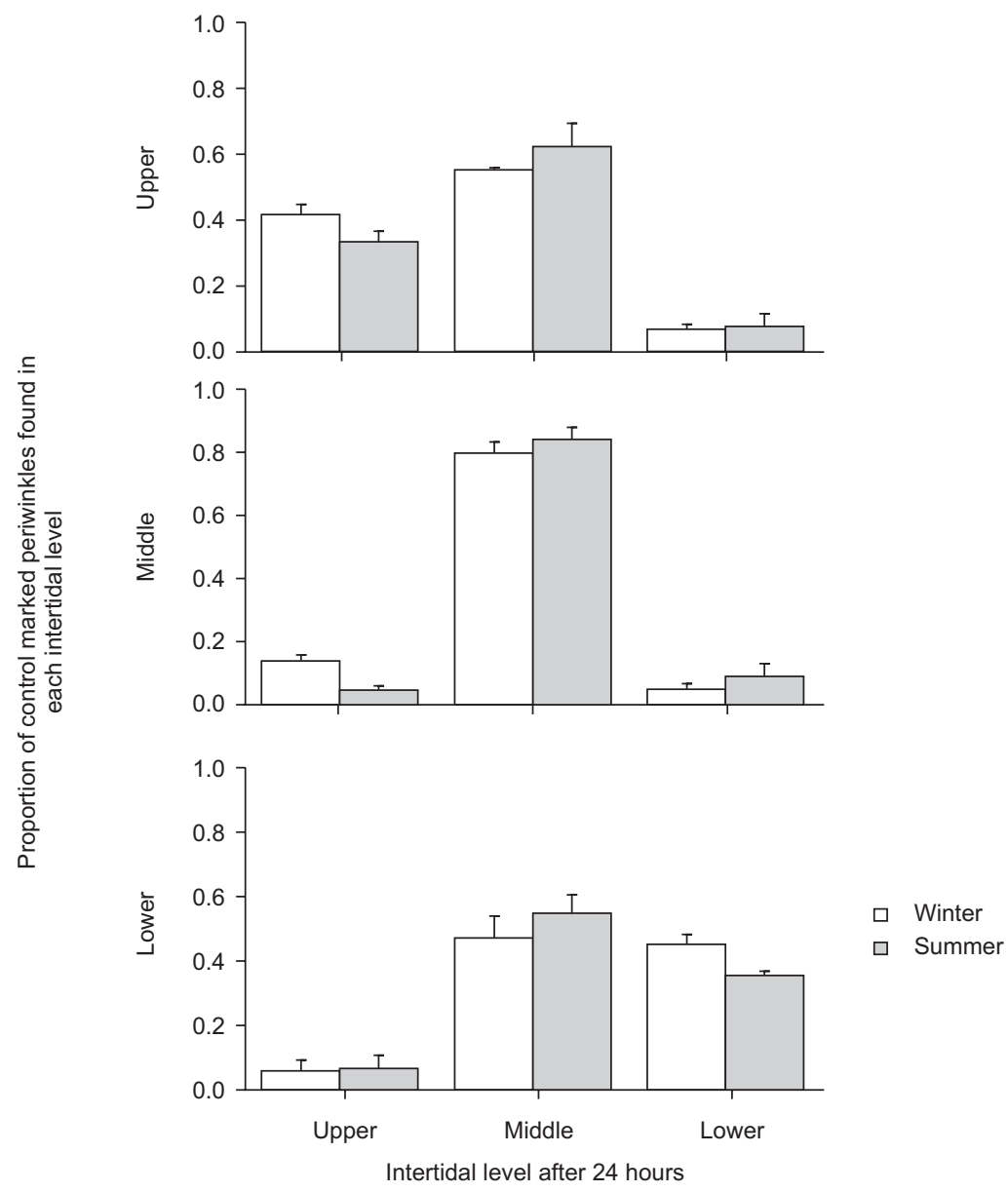

Fig. 2 - Distribution of marked periwinkles 24 hours after transfer to their zones of origin (control) at upper, middle, and lower intertidal levels for Winter and Summer experiments.

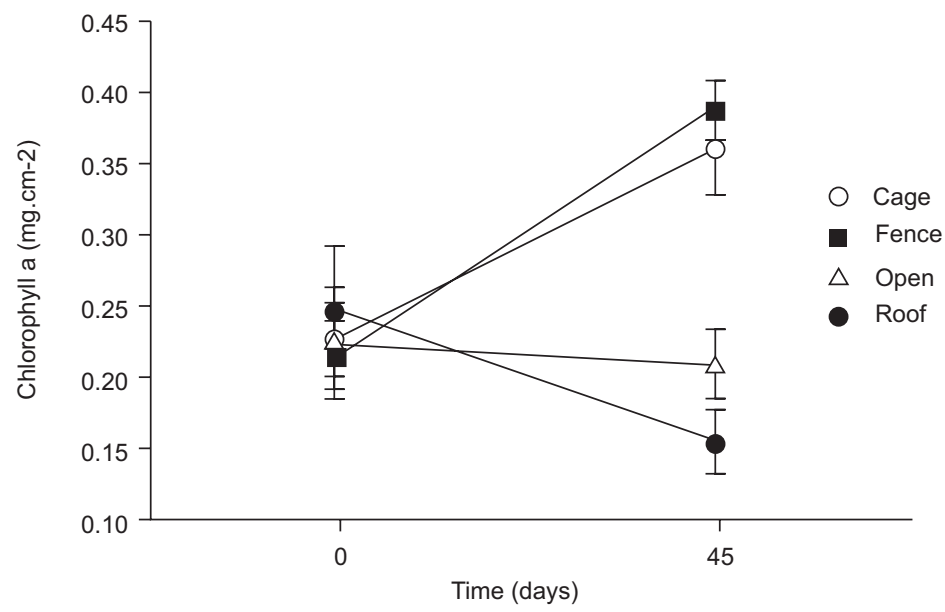

Fig. 3 - Chlorophyll- $a$ concentration (mean \pm SD) in each experimental treatment before and after the 45 day experiment. 
It is important to notice that the method excluded not only periwinkles, but also any other possible grazer. Due to this methodological restriction, we observed inside one cage, the growth of macroalgae (Ulva spp. and Enteromorpha spp.). Despite being observed inside only one cage, we understand that cages and fences excluded other grazers that affected the microhabitat inside the experimental plots. However, those potential grazers (specially the crab Pachygrapsus spp.) do not feed on the microalgae, and so we can assume that for what was being tested (concentrations of chlorophyll- $a$ ), periwinkles, the potential grazers of microalgae, were successfully excluded.

The ANOVA revealed significant differences among treatments, but not between time zero and after 45 days (Table 2). The clear difference between treatment that excluded and not excluded grazers made not significant the total difference through time, although each treatment isolated, shows a clear pattern of increasing or decreasing concentrations of chlorophyll- $a$ over time (Table 3).

\section{DISCUSSION}

The transfer experiment distributed marked periwinkles into their zones of origin (control), and other zones of the intertidal. The density of periwinkles transferred into the upper and lower intertidal levels was greater than the natural abundance of periwinkles at those levels, which may have caused density-dependent effects or handling disturbance (Petraits, 1982; Chapman, 1986).

TABLE 2

Two-way ANOVA table for concentration of chlorophyll- $a$ in 4 cage types before and after 45 days.

\begin{tabular}{|l|c|c|c|c}
\hline Source & D. F. & M. S. & F & P \\
\hline Treatments & 3 & 0.02 & 5.59 & 0.0047 \\
\hline Time & 1 & 0.01 & 3.59 & 0.0701 \\
\hline Treatments * time & 3 & 0.03 & 7.60 & 0.0010 \\
\hline
\end{tabular}

TABLE 3

Fisher's protected LSD test at three different significant levels of chlorophyll- $a$ among four cage types.

\begin{tabular}{|c|c|c|c|c|}
\hline & Vs. & Diff. & Crit. Diff & S. L. \\
\hline \multirow{3}{*}{ Roof } & Open & 0.02 & 0.06 & NS \\
\hline & Cage & 0.09 & 0.06 & $* *$ \\
\hline & Fence & 0.10 & 0.06 & $* *$ \\
\hline \multirow{2}{*}{ Open } & Cage & 0.07 & 0.06 & $*$ \\
\hline & Fence & 0.08 & 0.06 & $*$ \\
\hline Cage & Fence & 0.01 & 0.06 & NS \\
\hline
\end{tabular}

However, at the end of our experiments, the abundance of periwinkles in the experimental transects did not differ from those in undisturbed nearby areas.

Periwinkles move along a vertical intertidal gradient because of tidal influence (Warren, 1985), to escape from predators (Vaughn \& Fisher, 1988), and to search for shelter and crevices (Bosh \& Moreno, 1986). In fact, we cannot explain patterns of movements along an intertidal gradient by using one isolated hypothesis. All those above findings seem to have influenced on the pattern of distribution observed in our experiments, because of the way they aggregated at the middle intertidal, where the dominant organisms are barnacles. Barnacles could provide suitable microhabitat for periwinkles, considering their importance ameliorating the stress of the intertidal environment during the low tide, 
and the abundance of cyanobacteria and diatoms within the barnacle test (Baeta-Neves, 1988). Maclulich (1983) suggested that microalgal film is an indication of food availability for intertidal grazers; however, others have reported on the low edibility of microalgae (specially cyanobacteria) due to their mucilage (Calow, 1970; Hargrave, 1970). Castenholz $(1961,1963)$ examining the vertical distribution of diatoms concluded that where grazers were abundant, the distribution of diatoms was reduced. Nicotri (1977) determined that grazers considerably reduced the abundance of microflora, but she could not discern among the diets of grazers.

Our experiment demonstrated the importance of grazers in controlling the abundance of microalgal populations. We accept our hypotheses that the presence of periwinkles at the middle intertidal shore reduce the abundance of microalgal populations (but not extinguish them) and suggest that periwinkle pattern of aggregation at the mid intertidal is influenced by the availability of food at this intertidal level.

Acknowledgements - We gratefully thank the staff and professors at the Instituto de Estudos do Mar Almirante Paulo Moreira, who provided assistance for field experiment and laboratory investigations. Our colleagues: C. E. L. Ferreira, J. E. A. Gonçalves, M. A. Guimaraens, H. P. Lavrado, D. Pupo, and K. Sauer-Machado, were extremely helpful in the field. We also thank the professors and colleagues at Curso de Especialização em Biologia Marinha (UFF, RJ, Brazil), in special Jomar C. Filho for his support during the first draft of the manuscript. We extend our thanks to Professor T. Kikuchi and to Dr. K. Yamahira and Y. Takada for their constructive comments and suggestions. This study was supported by grants from Fundação de Amparo à Pesquisa do Estado do Rio de Janeiro (FAPERJ) and Conselho Nacional de Pesquisa (CNPq).

\section{REFERENCES}

BAETA-NEVES, M. H., 1988, Étude de Cyanophycees de la region de Cabo Frio (Rio de Janeiro, Bresil). Taxonomie et essai d'interpretation ecologique. Doctorales Specialité: Oceanologie Biologique Algologie. Dissertation, Université Pierre et Marie Curie, Paris 6, France.

BOSCH, M. \& MORENO, L., 1986, Spatial distribution of Littorina neritoides (L. 1758) (Mollusca, Gastropoda) in the supralitoral zone in the Balearic Islands. Cahi. de Biologie Marine, 42: 53-62.

BYERS, B. A. \& MITTON, J. B., 1981, Habitat choice in the intertidal snail Tegula funebraris. Mar. Biol., 65: 149154 .

CALOW, P., 1970, Studies on the natural diet of Lymnaea pereger obtusa (Kolbet) and its possible ecological implications. Proc. Malacol. Soc. London, 39: 203-215.
CAMPOS, M. Z. R., 1985, Estudos sobre o comportamento e distribuição espacial de Littorina ziczac. Monografia de Bacharelado em Biologia Marinha, Universidade Federal do Rio de Janeiro, Brasil, 33p.

CASTENHOLZ, R. W., 1961, The effect of grazing on marine littoral diatom populations. Ecology, 42(4): 783-794.

CASTENHOLZ, R. W., 1963, An experimental study of the vertical distribution of littoral marine diatoms. Limnol. Oceanog., 8: 450-462.

CHAPMAN, M. G., 1986, Assessment of some controls in experimental transplants of intertidal gastropods. J. Exp. Mar. Bio. Ecol., 103: 181-201.

CHAPMAN, M. G. \& UNDERWOOD, A. J., 1994, Dispersal of the intertidal snail, Nodilittorina piramidalis, in response to the topographic complexity of the substratum. J. Exp. Mar. Bio. Ecol., 179: 145-169.

CROWE, T., 1996, Different effects of microhabitat fragmentation on patterns of dispersal of an intertidal gastropod in two habitats. J. Exp. Mar. Bio. Ecol., 206: 83-107.

CUBIT, J. D., 1984, Herbivory and seasonal abundance of algae on a high intertidal rocky shore. Ecology, 65(6): 1904-1917.

FAIRWEATHER, P. G., 1988, Movements of intertidal whelks (Morula marginalba and Thais orbita) in relation to availability of prey and shelter. Mar. Biol., 100: 63-68.

FAUST, M. A. \& GULLEDGE, R. A., 1996, Associations of microalgae and meiofauna in floating detritus at a mangrove island, Twins Cays, Belize. J. Exp. Mar. Bio. Ecol., 197: $159-175$.

GARRITY, S. D. \& LEVINGS, S. C., 1984, Aggregation in a tropical neritid. Veliger, 27: 1-6.

HARGRAVE, B. T., 1970, The utilization of benthic microflora by Hyalella azteca (Amphipoda). J. Anim. Ecol., 39: 427-437.

JEFFREY, S. \& HUMPHREY, G., 1975, New spectrophotometric equations for determining chlorophylls a, b, c, and c2 in higher plants and algae. Biochem. Physiol. Pflanz., 167: 1991-194.

MACLULICH, J. H., 1983, Aspects of the ecology of intertidal epilithic microflora at Gree Point, New South wales. M.Sc. thesis, University of Sydney, 134p.

NICOTRI, M. E., 1977, Grazing effects of four marine intertidal herbivores on the microflora. Ecology, 58(5): 1020-1032.

PETRAITS, P. S., 1982, Occurrence of random and directional movements in the periwinkle Littorina littorea (L.). J. Exp. Mar. Bio. Ecol., 59: 207-218.

RAFFAELLI, D., 1985, Functional feeding groups of some intertidal molluscs defined by gut contents analysis. $J$. Molluscs Stud., 51: 233-239.

TAKADA, Y., 1992, The migration and growth of Littorina brevicula on a boulder shore in Amakusa, Japan. In: J. Grahame, P. J. Mill \& D. G. Reids (eds.), Proceedings of the 3rd International Simposium on Littorinid Biology, The Malacological Society of London, London, pp. 277-279. 
TAKADA, Y., 1995, Seasonal migration promoting assortative mating in Littorina brevicula on a boulder shore in Japan. Hydrobiologia, 309: 151-159.

UNDERWOOD, A. J., 1984a, Microalgal food and the growth of the intertidal gastropods Nerita atramentosa (Reeve) and Bembicium nanum (Lamark) at four heights on a shore. J. Exp. Mar. Bio. Ecol., 79: 277-291.

UNDERWOOD, A. J., 1984b, The vertical distribution and seasonal abundance of intertidal microalgae on a rocky shore in New South Wales. J. Exp. Mar. Bio. Ecol., 78: 199-220.

UNDERWOOD, A. J., 1984c, Vertical and seasonal patterns in competition for microalgae between intertidal gastropods. Oecologia (Berlim), 64: 211-222.

UNDERWOOD, A. J. \& CHAPMAN, M. G., 1989, Experimental analyses of the influences of topography of the substratum on movements and density of an intertidal snail, Littorina unifasciata. J. Exp. Mar. Bio. Ecol., 134: 175-196.
VAUGHN, C. C. \& FISHER, F. M., 1988, Vertical migration as refuge from predation in intertidal marsh snails: a field test. J. Exp. Mar. Bio. Ecol., 123(2): 163-176.

WARREN, J. A., 1985, Climbing as an avoidance behavior in the salt-marsh periwinkle, Littorina irrorata (Say). $J$. Exp. Mar. Bio. Ecol., 89(1): 11-28.

WATSON, D. C. \& NORTON, T. A., 1985, Dietry preferences of the common periwinkle, Littorina littorea (L.). J. Exp. Mar. Bio. Ecol., 88(3): 193-211.

WATSON, D. C. \& NORTON, T. A., 1987, The habitat and feeding preferences of Littorina obtusa (L.) and Marie Sacchi et Rastelli. J. Exp. Mar. Bio. Ecol., 112(1): 6172. 